\title{
The Structure of Treasury and Foreign Exchange
}

\author{
Taqi Aldeen T. Mhamod Darbi, Suleiman Essa Al Aazzabi \\ Treasury Department, National Commercial Bank (NCB), Tripoli, Libya \\ Email: taqialdeendarbi@gmail.com
}

How to cite this paper: Darbi, T.A.T.M. and Al Aazzabi, S.E. (2021) The Structure of Treasury and Foreign Exchange. Open Access Library Journal, 8: e7968.

https://doi.org/10.4236/oalib.1107968

Received: September 14, 2021

Accepted: December 20, 2021

Published: December 23, 2021

Copyright $\odot 2021$ by author(s) and Open Access Library Inc.

This work is licensed under the Creative Commons Attribution International License (CC BY 4.0).

http://creativecommons.org/licenses/by/4.0/

\section{Open Access}

\begin{abstract}
Treasury is characterized as the administration of resources and liabilities to upgrade return using monetary instruments through Foreign Exchange and can be characterized as the transformation of one money into another. Customarily foreign exchange is derived from global exchange. Both the shipper and the exporter should consider trade rates to empower them to value their stocks. In whichever money the receipt is named, foreign is required. Today around $95 \%$ to $98 \%$ of this day-by-day turnover is hypothetically based. Considering this enormous theoretical turnover, markets are presently associated with a modern correspondences organization and are observed by members by the utilization of computers.
\end{abstract}

\section{Subject Areas}

Finance

\section{Keywords}

Foreign Exchange, Treasury, Central Banks, Risk Management, Interests

\section{Introduction}

\subsection{Definition of Foreign Exchange}

What is Treasury? Treasury is the administration of resources and liabilities to advance return through the utilization of monetary instruments. In this paper we will present the Job of Treasury, the Design of Treasury, the Tasks of Depository, the Local Treasury Habitats and Gathering Treasury Activities.

Exchanging is currently 5 days every week, 24 hours daily working around the world. Significant business sectors exist in Australia (Sydney), Japan (Tokyo), Hong Kong, Singapore, Joined Realm (London), US of America (New York), 
Canada (Toronto) and Germany (Frankfurt).

Foreign Exchange is the conversion of one currency into another. It is anything but an essential piece of the world monetary framework. Without unfamiliar trade, numerous parts of our everyday life which we underestimate would not exist (Ambrose, B. and Wargi) [1].

\subsection{Importance of Foreign Exchange}

At the point when you go into a shop and purchase something which is manufactured abroad, regardless of whether it is anything but a Swiss watch, some French wine, a Japanese TV set, or a German engine vehicle, you cause a foreign arrangement to occur. How would you pay for them? In your home money obviously yet does the maker of merchandise or supplier of administrations gets paid in his own money. In the middle, an exchange needs to happen changes over your money into cash of the maker or on the other hand specialist organization. That exchange is attempted in the foreign exchange market. Allow us to utilize some French wine savored in the US for instance; there are two different ways in which the money manager who sells in the USA can pay the wine provider who lives in France. The primary path is to send US dollars to France. The provider, nonetheless, cannot typically spend these in his own country. $\mathrm{He}$ would need to trade them for Euros. In this situation, the French provider and his financier total a foreign exchange. Each will take one sort of public cash and give the other. There is also another method of paying; the French provider may request that the American finance manager pay in Euros. In this situation, the solicitations the purchaser in Euros. The purchaser needs to go to his bank in the US to trade US dollars into Euros and afterward send these to France. The foreign exchange bargain is finished between the purchaser and his bank in the US (Bierwag, G. O. and Kaufman, G. G.) [2].

Regardless of whether the foreign bargain is done in France or the US, it does not influence the fundamental nature of exchange. On the off chance that a deal including cash has been closed between inhabitants of various cash regions, it is anything but a foreign bargain. Foreign exchange is simply the trading of one cash for another.

It resembles some other agreement in that one thing is traded for another. Be that as it may, there is one significant distinction between a foreign exchange, what is more, an ordinary exchange. Normally we trade cash for merchandise or products for cash. In foreign cash is traded for cash. In worldwide exchange, organizations embrace ordinary deals. They purchase, sell, get what is more, loans. In any case, in selling and purchasing, they embrace exchanges that cross global limits. So, if one organization offers products to an abroad purchaser and anticipates installment in his own money, the purchaser should pay the merchant in what, as far as he might be concerned, is unfamiliar cash (Ambrose, B. and Wargi) [1].

It may keep an unfamiliar money account with his bank in the cash of installment on the off chance that he anticipates customary receipts in that money. 
For instance, the French vendor may keep a US dollar money account with his bank to meet the customary receipts in that money. This would likewise empower him to make customary installments in that money. So, by keeping a cash account he may try not to need to pay and sell unfamiliar cash each time he makes a deal or buy-in that money. Anyway, it ought to be noticed that the French vendor in the above model can request that his bank clutch the unfamiliar cash got. He may maybe put it as anything but an interest-bearing record until it is needed to make an installment later (Black, F) [3].

Regardless of whether the foreign bargain is done in the neighborhood cash of the French vendor or the foreign currency, it includes the requirement for foreign global exchange.

\section{Brief Development History of Foreign Exchange}

It is significant in contemplating foreign exchange to see unmistakably the importance of certain specialized wording and market phrases. The Foreign exchange hypothesis is a subject that is best understood? scholarly by completely seeing instead of learning by heart. Foreign exchange is anything but a groundbreaking thought. The changing of cash has been essential for the matter of cash since coins were stamped. The first forward trade exchanges can be followed back to the cash transformers in Lombardy during the 1500s. In 1825, at the Congress of Vienna, the significant force supported a set of rules for global monetary direct which set up the establishment of the present financial framework [4].

The exchange system is the oldest exchange method and was established in 6000 BC. Introduced by the Mesopotamian tribe. As part of the exchange system, the item has been exchanged for another item. Since then, the system has evolved and products such as salt and spices have become popular mediums of exchange. The ship set sail to exchange these goods in the form of the first foreign exchange. After all, the first gold coins that functioned as early as the 6th century BC currency had decisive properties such as portability, durability, divisibleness, uniformity, limited availability, and acceptance. Manufactured 4444 gold coins were widely accepted as a medium of exchange, but they were heavy and impractical. In the 1800s, each country adopted the gold standard. The gold standard guaranteed that the government would exchange any number of banknotes for the value of gold. This worked until World War I, when European countries had to suspend the gold standard to print more money to pay for the war [5].

The Forex market was supported by the gold standard at this time and in the early 1900s. The countries traded with each other because they were able to convert the currency they received into gold. However, the gold standard could not withstand during World War II.

\section{Effect Exchange Rate Fluctuations on Market}

We are occasionally most likely mindful that paces of trade vary, so one money 
debilitates furthermore, subsequent money reinforces corresponding to another. Swapping scale vacillations influence a genuine danger to abroad merchants, and this cash hazard is a significant part of Foreign Exchange dealings. Here and there trade rates keep on fluctuating at whatever point they are permitted to react to the pressing factors of supply and request in the Foreign Exchange markets. The significant impact of fluctuating trade rates for global exchange is the danger for exporters and merchants that the worth of Foreign Exchange they may need to bargain in ends up being unique about what they had trusted and planned (Carleton, W. T., Chambers, D. R. and McAnally) [6].

- SUPPLY AND DEMAND: is monetary ideas identified with market circumstances. If specific cash is copious and is being offered by numerous sellers available, it will in general become less expensive as far as different monetary standards that are being bought in return. Then, at that point, the cost of the money being promptly provided and made available for purchase will fall. Then again, if cash is sought after, and a couple of individuals are making it available for purchase, the cost of that money will rise. In this manner, variances in return rates are brought about by an abundance of market interest, or the other way around. For instance, if the interest of clients to get US dollars and sell real surpasses the counterbalancing request to purchase authentic and sell US dollars, real will lose esteem against US dollars. However, the following factors are known to affect rates of exchange:

The balance of payment is considered as the distinction between what the country procures and what it spends. At the point when a nation trades in esteem a greater number of labor and products than it imports, the nation will procure more unfamiliar cash than it spends. For instance, if the UK exporters procure more than their merchants need to pay out, this will bring about excess on the UK equilibrium of exchange. On the off chance that the UK finance managers need to acquire real and not unfamiliar money, there will be an interest for the financial specialists to sell unfamiliar money excesses in return for real. Then, at that point, the market pressing factor of market interest will make an expansion in euthenics' worth against different monetary standards. This could increment euthenics' worth against different monetary forms.

From the above focuses we can see that an equilibrium of installments excess or shortage will influence the current paces of trade between monetary standards. The impact of equilibrium of installments overflow will make an interest for the country's cash which will increment in esteem as far as different monetary forms. When other factors stay unaltered, there will be more cash streaming into the country than emerges from it. Henceforth, more abroad purchasers need the cash to pay for their imports from the country. Such interest will cause the money to increment in esteem. Then again, a nation enduring an equilibrium of installments shortfall will find that its money debilitates or falls in esteem.

Confidence and speculation:

Certainty of dealer's later position of a specific nation depends maybe on hy- 
pothesis. It will likely influence their cited rates for the cash of that country. On the off chance that there is the chance of a conflict, a strike, or a chance of an adjustment of government in a country, it will incite financial backers to sell the cash of that country. This would empower them to get the preferable pace of trade now over what they would do if the money of that nation were to fall in esteem.

Certainty, or absence of it, can prompt theory in money. On the off chance that individuals think money will debase, they wish to ensure themselves by ensuring they have none of that cash on their books. On the off chance that theory is against cash, financial backers will sell that money. If the hypothesis is supportive of money, financial backers purchase that cash. In this way, if the hypothesis becomes solid, the pressing factor of interest possibly in support of the money will constrain conversion standard developments toward the path proposed by examiners. Speculative powers can majorly affect trade rates.

Central bank intervention and exchange controls:

A national bank may mediate in the market to purchase or sell its homegrown money when the public authority has an arrangement of fixed rates. It may permit its cash to cost or permit just restricted changes in the rates for its money.

At the point when the public authority has an arrangement of fixed trade rates, intercession would be made to forestall a cheapening of the money by paying the cash and auctioning off some foreign exchange saves.

It may likewise forestall revaluation of the money by selling the cash in return for the foreign monetary standards. At the point when the public authority permits its money to drift, the national bank may, in any case, mediate to purchase or sell its cash, if the public authority thinks that the conversion scale for the money has appreciated or deteriorated to an unmerited level [7].

Now and again an administration permits just restricted vacillations in return paces of their money. So, there will be an intercession point where the national bank will mediate once the cash has appreciated or devalued to a limit level (Black, F) [4].

\section{International interest rate differentials:}

Exchange control guidelines can likewise influence trade rates. The presentation of new guidelines which confine the free development of assets will cause a decrease popular for cash. On the other hand, the unwinding or cancelation of trade control guidelines will make for a more liberated market in that country's money and will for the most part lead to an expanded interest.

\section{Leads and lags:}

("Leads" methods a race to pay in cash in front of the time regularly picked for installments. "Lags" signifies a postponement in installment or offer of cash.)

\section{Hot money:}

An immense amount of global cash is accessible for ventures or theoretical purposes. At the point when it is utilized for venture the cash moves starting with one country then onto the next to get the advantage of higher loan costs. At the point when it is theoretical it is cash that will move from feeble money into a 
more grounded one with the expectation that the more grounded cash will build its worth and empower a capital benefit to be made. Equivalent to hot cash streams into a country, it can similarly as fast stream out, putting speculative tension on the country's cash to debilitate.

\section{Treasury Role}

\subsection{Depository}

There will be sure items and administrations that a specific dealing room will not effectively give. It is significant for the Treasury Chief to guarantee to utilize accessible assets by focusing on regions that will give the greatest return on the bank's venture. The job of Depository can be isolated into three regions:

1) It deals with the bank's accounting report as far as subsidizing resources and liabilities and financing cost openings. To satisfy this obligation Treasury utilizes every one of the apparatuses accessible to them as far as items. These are from fundamental spot to financing cost trades, and the executives' data-driven by the bank's center frameworks.

2) It effectively makes hazard positions to create exchanging pay, for example, unfamiliar trade.

3) It fulfills client needs by offering proficient and serious assistance, for example, foreign exchange items and Treasury items.

The essential capacity of every one of the bank's Treasury places all through the globe is the itemized board of the bank's resources and liabilities which fall inside their circle of duty. They have explicit obligations regarding:

1) Maximizing profitability through trading and marketing treasury products.

2) Monitor interest rate risk.

3) Monitor exchange risk.

4) Monitor credit risk.

5) Monitor cash flow, where it arises from treasury activities and liquidity.

6) Developing Treasury capabilities and the presence in the marketplace.

Stress that the Depository must control all parts of the abovementioned capacities and guarantee that all dangerous positions made in different spaces of the bank are taken in under the Treasury umbrella. In some cases, intermediaries are employed who go about as middle persons between banks. They get a commission from the two banks associated with the exchange. Agents' rates acquired from one additional bank are genuine managing rates. Treasury capacities assume a significant part in the bank's tasks (Dimson, E. and Marsh, P) [8].

\subsection{Structure of Treasury Department}

The dealing room is a region inside the bank answerable for the buy and offer of monetary standards, and the administration of bank reserves. All managing room staff act autonomously inside foreordained exchanging cutoff points and reference to a predominant isn't needed except if the cutoff is surpassed. All managing room staff is decided on benefit, business improvement, and innova- 
tiveness. Exchanging limits increment with the rank of position.

The Trainee is attached to Dealer learn frameworks and hardware, market practice, and fundamental item information while Vendor is liable for student improvement, relegated higher exchanging limits with more prominent benefits anticipated. $\mathrm{He}$ is answerable for relationships working with clients and the bank. Unit Head/Senior Seller guarantees segment works effectively, beneficially, and inside foreordained cutoff points and different obligations comparable concerning Seller. Boss Seller is liable for the everyday activity of managing room and guarantees it works proficiently, productively, and inside foreordained cutoff points. Different obligations are the same concerning the Vendor (Duffey, G. and Giddy) [9].

The supervisor is eventually answerable for managing the room and administrative center which includes departmental strategy choices. He should guarantee consistency with Central bank guidelines and regulates day by day activity of the dealing room, for example, limits proportions. He likewise directs productivity and guarantees managing morals are maintained. Last however not least is staff improvement.

- Front office: The fundamental of the dealing room is where the dealers in treasury and cash markets items are found. In the Depository habitats, the bank's center depository exchanging framework has now been carried out in the dealing rooms. Treasury Trading System has now been carried out in the dealing rooms and this framework will be talked about later. The pay-creating side of the Depository will ordinarily be parted into explicit spaces of duty or Benefit Focuses. Inside each benefit community will be sub-exercises or sub-benefit focuses which might address a portfolio or a person.

The front office has many elements that are dependent on workways and operations, Technology forms a significant piece of everyday life in Depository giving data interchanges and handling capacities. Dealing room hardware incorporates phone, message, voice recorder, watch, and PCs. Communications in the dealing room activities are through Bloomberg/Thomson Reuters managing administration.

The help is utilized in managing space for interchanges and activities. Bloomberg and Thomson Reuters machines are given in the managing space for the show of trade/financing costs to give data to news administration of trade and financing costs so vendors can settle on quick and better choices.

A regular dealer's desk area is contained items: Bloomberg, Thomas Reuters, Telerate, Data Framework, and Correspondence. In certain locales the Bloomberg/Thomas Reuters and Telerate news page can be gotten to through the terminal, subsequently decreasing the requirement for isolated Bloomberg /Thomson Reuters/Telerate terminal.

In the Bloomberg/Thomson Reuters machines, two news administrations are given. They are consistently refreshed. They give general news and game just as nitty-gritty monetary reports. 
Trade/financing costs showed are for data as it were. They are not managing rates.

Bloomberg/Thomson Reuters Direct Managing is a high-level type of correspondence. Each supporter of the framework is appointed a code. A vendor contacts the supporter by entering the code.

Discussions are shown on screen. Phone Direct Association is the phone direct interface with merchants, banks, and clients. Merchants go about as middle people between banks. They get a commission from the two banks engaged with the exchange. Dealers' rates, gotten from at least one bank, are genuine managing rates. There is a console for vendors' utilization. Brokers Boxes give a steady exceptional wellspring of data to the vendor on what costs are cited on the lookout. Figure 1 explained the workflow of the front office and running for dealings in the market.

- Back office: The back office should be a discrete working unit from the dealing room. The fundamental administrative center capacities are to deal with everything bargains done by the sellers. This includes:

1) Acquiring autonomous check of arrangement subtleties straightforwardly with each counter gathering and making any settlement as required.

2) Guaranteeing an affirmation is dispatched and gotten for each arrangement struck.

The back-office tasks are additionally associated with various other control capacities and regularly give the executive's data backing to the sellers and Depository directors. In rundown, the administrative center guarantees bargain ticket is clear, accurately ready, approved constantly if modifications are made. The administrative center alludes to questionable exchanges to Director, processes transactions, and dispatches "Payment/Receive" instructions.

- Asset-Liability Management (ALM): Present-day banking might be characterized as development intermediation or hazard intermediation. Bank gathers stores from clients with different developments going from 7 days to 5 years (however there is no bar on longer-term stores, significant banks debilitate stores for longer-terms to stay away from financing cost hazards).

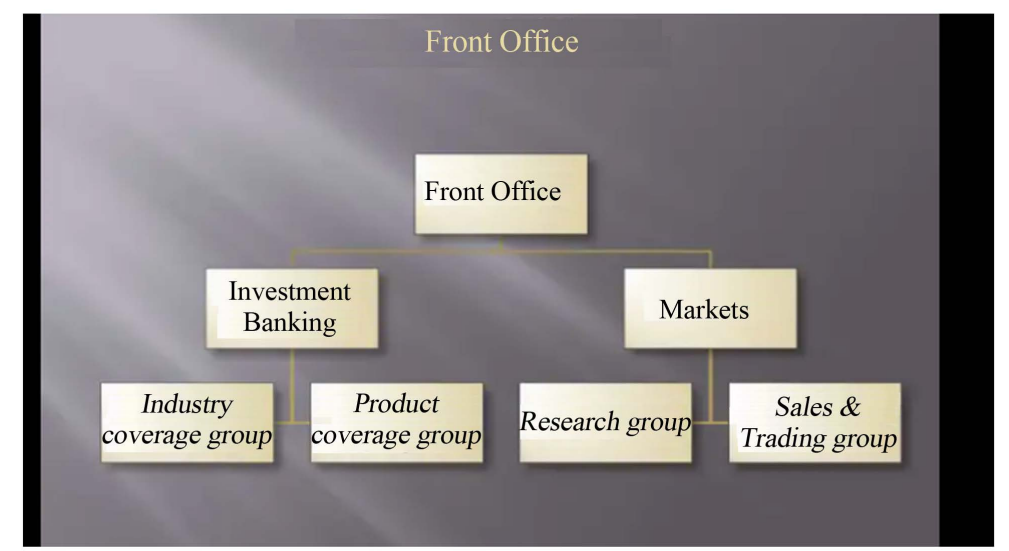

Figure 1. Front office. 
The assets so gathered alongside capital assets and call borrowings are loaned to borrowers with shifting developments, going from an overdraft for a couple of days to contract credits of, say 15 years. In this way, the bank alters and broadens developments that the retail investors themselves couldn't stand (Evan off, D. D.) [10].

Likewise, while the investors have guaranteed security of assets along with premium, the bank doesn't have a similar solace while loaning or putting assets in different roads full of market hazard and credit hazard-in this manner the bank additionally retains hazard which singular contributors couldn't all alone do.

While the credit hazard of a bank is self-evident and is overseen traditionally through successful credit oversight, what isn't so clear is the market hazard, which is shown as liquidity hazard and financing cost hazard in financial tasks (Abbozzi, F. J) [11].

Asset Liability Management (ALM) can be characterized as a component to address the risk faced by a bank because of a jumble among resources and liabilities either because of liquidity or changes in loan fees. Liquidity is an establishment's capacity to meet its liabilities either by acquiring or changing over resources.

- Middle office: A Middle Office user is dependable to implement and survey hazard cutoff points and special cases while an administrative center capacity is liable for settlement, affirmation, and bookkeeping. TROPS or Depository Tasks is by and large used to allude to the depository administrative center gatherings

Finally, Figure 2 shows all actions tracked for dealings by a detailed system wide audit trail and describes the steps from ticket deal by front office till back office authorize (Friedman, R. M. and Roberts, W. W) [5].

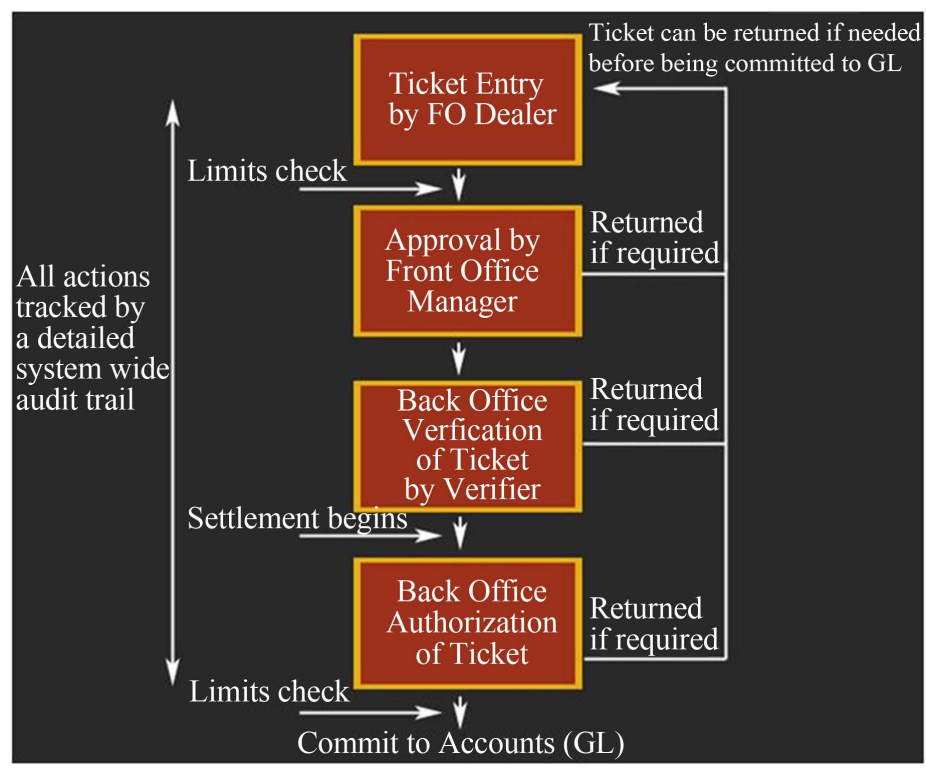

Figure 2. All actions tracked by a detailed system wide audit trail. 


\section{Conclusions}

The reason for writing this paper is to furnish peruses with explicit information on foreign exchange and crafted by the bank's Foreign Exchange and Treasury Department. The exploration article covers the useful and procedural parts of the business related to unfamiliar trade including the elements of the Treasury and foreign exchange department, the job of foreign exchange, the bank's foreign exchange administrations, and the Treasury Trading Framework. It additionally gives an outline of the foreign exchange market and its job as well as fundamental information on its activities.

This paper discusses role treasury department and foreign exchange to improve and develop financial systems in Libyan banks to depend as reference.

Nowadays there are some banks that have Treasury departments work via structure explained in beginning of this paper for example: Central bank of Libya, Libyan Foreign Bank and National Commercial Bank.

\section{Conflicts of Interest}

The authors declare no conflicts of interest.

\section{References}

[1] Ambrose, B. and Wargi, A. (1996) Yield Bogeys. Financial Analysts Journal, 52, 63-68. https://doi.org/10.2469/faj.v52.n5.2025

[2] Bierwag, G.O. and Kaufman, G.G. (1985) Duration Gap for Financial Institutions. Financial Analysts Journal, 41, 68-71. https://doi.org/10.2469/faj.v41.n2.68

[3] Black, F. (1975) Bank Funds Management in an Efficient Market. Journal of Financial Economics, 2, 323-339. https://doi.org/10.1016/0304-405X(75)90008-2

[4] Black, F. (1986) Noise. Journal of Finance, 41, 529-543. https://doi.org/10.1111/j.1540-6261.1986.tb04513.x

[5] Friedman, R.M. and Roberts, W.W. (1983) The Carry-Forward Provision and Management of Bank Reserves. Journal of Finance, 38, 845-855. https://doi.org/10.1111/j.1540-6261.1983.tb02505.x

[6] Carleton, W.T., Chambers, D.R. and McAnally, R.W. (1988) Immunizing Default-Free Bond Portfolios with a Duration Vector. Journal of Financial and Quantitative Analysis, 23, 89-104. https://doi.org/10.2307/2331026

[7] Diamond, D.W. (1997) Liquidity, Banks, and Markets. Journal of Political Economy, 105, 928-956. https://doi.org/10.1086/262099

[8] Dimson, E. and Marsh, P. (1995) Capital Requirements for Securities Firms. Journal of Finance, 50, 821-851. https://doi.org/10.1111/j.1540-6261.1995.tb04038.x

[9] Duffey, G. and Giddy, I.H. (1984) Euro Currency Deposit Risk. Journal of Banking and Finance, 8, 567-589. https://doi.org/10.1016/S0378-4266(84)80047-3

[10] Evanoff, D.D. (1990) An Empirical Examination of Bank Reserve Management Behavior. Journal of Banking and Finance, 14, 131-143. https://doi.org/10.1016/0378-4266(90)90040-9

[11] Abbozzi, F.J. (1996) Bond Markets, Analysis and Strategies. 3rd Edition, Prentice Hall International. 